\title{
Bird species richness, evenness and habitat management around airports: a case study of Benazir Bhutto International Airport Islamabad, Pakistan
}

\author{
Sameera Arshad ${ }^{1}$, Arshad Mahmood Malik ${ }^{2}$ \\ ${ }^{1}$ Department of Wildlife Management, PMAS-Arid Agriculture University, Rawalpindi, 46300, Pakistan \\ ${ }^{2}$ Department of Economics, PMAS-Arid Agriculture University, Rawalpindi, 46300, Pakistan
}

Received:

June 03, 2019

Accepted:

August 16, 2020

Published:

October 31, 2020

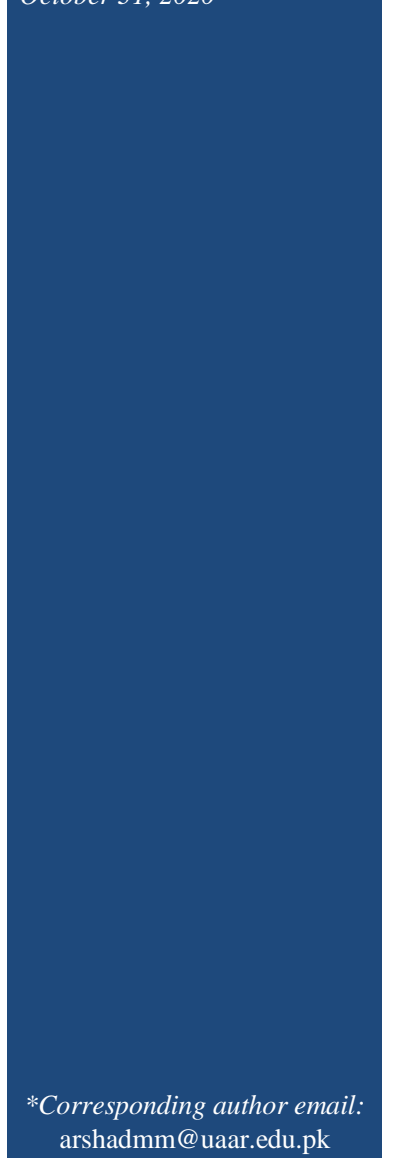

\begin{abstract}
Birds in the vicinity of airports pose threat to the aircraft. These collisions may result in huge economic losses and is also compromise passenger's safety. Identification of potential hazardous species, present at and in the vicinity of any airfield, is vital to improve bird hazard management at the airfields. Data of bird species present in the vicinity of BBI airport were collected by using point count method from eight different sites, representing different habitats, located around the airfield of the Benazir Bhutto International Airport, Islamabad. These sites represented commercial area around hotels, commercial habitat, naturally preserved recreational area, buildings with old pine trees, a water body, a sports ground, a landfill site, and a modern housing society. Data were analyzed for species density and relative abundance in each habitat, using the Simpson biodiversity index, Margalef diversity index, and clustering methods. Mean bird density in the area was found to be $0.0013 \mathrm{bird} / \mathrm{m}^{2}$. Highest bird density was found to be of crow followed by kites and house martin as $0.0068,0.00269$ and 0.00206 birds $/ \mathrm{m}^{2}$ respectively. K-dominance species abundance model reflected the presence of kite as dominant species. Mean Simpson diversity index of 1.91 indicated the richness and evenness of species. Similarity index was found to be maximum to a value of 80.81 percent at commercial sites and lowest at modern housing society. Results of the study revealed that different habitats around the airport supported different species, thus, in order to formulate effective management plan for the airfields, species identification, richness, evenness and bird behavior should also be taken into consideration.
\end{abstract}

Keywords: Kite, Hazardous bird species, Bird habitat, Pakistan, Species density, Species richness and evenness, Islamabad

\section{How to cite this:}

Arshad S and Malik AM, 2020. Bird species richness, evenness and habitat management around airports: a case study of Benazir Bhutto International Airport Islamabad, Pakistan. Asian J. Agric. Biol. 8(4): 413-421. DOI: https://doi.org/10.35495/ajab.2019.06.237

This is an Open Access article distributed under the terms of the Creative Commons Attribution 3.0 License. (https://creativecommons.org/licenses/by/3.0), which permits unrestricted use, distribution, and reproduction in any medium, provided the original work is properly cited.

\section{Introduction}

Birds' prevalence in the vicinity of an airfield is hazardous for flight operations. Any bird whether small or large, has the potential to cause damage to an aircraft. Apparently, it looks difficult to assess which 
species is more hazardous to the aircraft, but over time research has developed standard methods to do this sort of evaluation. DOC 9137, Airport Services Manual: Part 3, on Wildlife Control and Reduction (International Civil Aviation Organization) recommends certain standards and procedures to be followed for bird hazard assessment. For this purpose, bird species present in the target area are first identified and counted, and then their population and movement in that area are recorded. It is assumed that larger the bird, the greater the damage to the aircraft would be. There are also more chances of a strike with flock of same species. Birds flying at high altitude also pose serious threat to aircraft.

Identification of bird species involved in bird strike is an integral part of aerodrome bird hazard management. Knowledge about species gives clues about size, behavior, breeding and feeding patterns of the problematic bird species and hence, preventive measures could be taken accordingly. Bird species identification is one of the major issues being faced by Civil Aviation Authority and Pakistan Air Force in Pakistan.

Since all bird species are not hazardous to the aviation, therefore, it is important to identify the species of conflict and the factors responsible to attract them to or near the airports/airfields. In USA, 21 hazardous bird species were identified among them the vultures and geese were ranked at number one and two, respectively (Dolbeer et al, 2000). The third lowest ranked group included small birds that form large flocks such as; blackbirds, starlings, sparrows and swallows. European starlings, gulls, rock pigeons and crows were involved causing hazards to aircraft safety in 7 US states (Washburn and Seamans, 2007). In North America and Europe population of many species of gulls was increasing (Belant, 1997). Their abundance in urban areas has resulted in many conflicts with people including threat to aviation. Gulls accounted for 84 percent of bird strikes averaging 260 strikes per year at John F. Kennedy International airport, New York USA during 1998 (Dolbeer, 1998). Many factors like protection from human disturbance, reduction in environmental contaminants, availability of food and gulls' ability to adapt to anthropogenic environment has resulted in rise in their population. Gulls' abundance in urban areas not only had many clashes with humans but also they become hazardous to aircraft safety.

The population status and dynamics for damage management plays a significant role in bird attraction
(Dolbeer, 1998). Population models are essential to analyze how population will respond to proposed management action for example, raptors are also attracted to airports due to rodent's activities (Witmer and Fantinato, 2003; Bildstein, 2017). Reduction of rodent population at an airport may decrease raptor population in an area and, therefore, can reduce the risk that raptors pose to aircraft. Albatrosses were also found potential hazardous species at Midway Naval Air Facility (Dolbeer et al., 1996). The U.S. Navy in 1993 reported 57 strikes during 459 aircraft movement. Species composition and diurnal pattern of bird flight over runway 6/24 were observed and recorded a mean of 363 birds crossing the runway per minute during day light hours. At night only 5-7 birds per minute were flying over the runway, a 98.5 percent difference over mean numbers during day light. It was recommended that nonemergency movements should be restricted to night from November-mid July as day time air movement would raise serious safety issues. Similar studies have also been conducted in South Asia. Raptors such as kites, eagles, vultures and falcons were found as the main hazardous species at Tribhuvan International Airport, Kathmandu, Nepal (Upadhyaya and Dolbeer, 2001). Pariah kites were found to be very abundant and threatening species in five different airports in India (Matthew et al., 1998). Kites are also becoming problem at many airports in Pakistan according to Civil Aviation Authority Pakistan (CAA, 2017). The purpose of current study was to identify bird species, richness, evenness and their habitat preference around Benazir Bhutto International Airport Islamabad, Pakistan, so that the results of the study could be utilized for better management practices.

\section{Material and Methods}

Time-area count survey/fixed point count method was used to collect data for estimation of bird species densities of target bird species (Servoss et al., 2000), from eight different study sites, in the vicinity of Benazir Bhutto International Airport, Islamabad, Pakistan. The significance of selecting point count method over other counting methods is that the mean number of detections obtained by using fixed radius point count could also be used to test bird abundance and differences in community composition among selected sites (Hutto et al., 1986). Optimal interval of point count provides more accurate species richness (Mattos and Peris, 2008). The $50 \mathrm{~m}$ radius selected 
was large enough to ensure counting of species of interest.

\section{The point count method \\ Data collection}

Data on bird species and number were collected from eight different study sites representing eight different habitats, i.e. commercial habitats, habitat with buildings having tall trees, naturally preserved recreational areas, habitat near water bodies, habitat near sports ground, garbage dumping sites and habitat covering modern housing societies. At each vantage point data were recorded as follow:

1. The number of individuals of each bird species falling within $50 \mathrm{~m}$ radius.

2. Birds that were observed outside the $50 \mathrm{~m}$ radius boundary but afterward moved to within $50 \mathrm{~m}$ radius were counted as present within fixed-radius.

3. Birds species observed, while travelling between points were also identified and recorded. Though, this count between points was merely to the mark presence of bird species in that particular habitat but was not part of the count data used in this analysis. These bird species were recorded as present $(+)$.

Birds surveys were carried out biweekly during oneyear study period. At each visit each habitat/site was visited for 15-20 min and the birds were counted for 3-5 minutes in a fixed radius (Hingston et al., 2018). Starting time of each bird count was altered between dawn and dusk based on season. The census began an hour or so after sunrise and finished before 10:30 am. The noon data were recorded between 1200-1500 hours. The dusk observations were started an hour before sunset till half an hour after sunset (Dénes et al., 2018). Binocular were used only to confirm observations and to identify species not clear with naked eyes (Servoss et al., 2000). The survey route was reversed at alternative observation. All the necessary information like, name of site, date, time, bird species, numbers observed, activity (categorized according to flying, loafing nesting, feeding, breeding etc.) habitat type were recorded at each observation.

\section{Target species}

Preliminary interviews/discussions with Civil Aviation Authority and Pakistan Air Force personnel revealed that bird species posing threats to aviation at Benazir Bhutto International Airport, Islamabad; Pakistan were kites, house crows, pigeons, common myna, house sparrows, and flocks of some unidentified small birds. These bird species were considered as the species of interest for this study. For estimation of target bird species density focus was mainly on Kite (Milvus migrans), as kites were found to be involved in 72 percent of all strikes with known bird species, and the objective was not to estimate density of every species but to establish an index of abundance of the most hazardous species (Servoss et al., 2000).

\section{Parameters of study Species density}

Species density was used to estimate population of birds belonging to each species.

Species Density $=\frac{\text { Total number of individuals of one species }}{\text { Total area of the sampled circle }(\pi \times \mathrm{r} 2)}$

\section{Relative abundance}

Relative abundance of each bird species was calculated by following K-Dominance Species Abundance Model (Plummer et al., 2019).

In addition to most abundant species was calculated by

Relative abundance: $\frac{\text { Total number of individuals of one species }}{\text { Total number of individual of all species }} \times 100$

\section{The Simpson Biodiversity Index}

Species diversity of each habitat was calculated by using Simpson Biodiversity Index (Lazebnik et al., 2017). Simpson's Diversity Index is a measure of diversity which takes into accounts both richness and evenness. Species richness is the number of different species present. However, diversity depends not only on richness, but also on evenness. Evenness compares the similarity of the population size of each of the species present. As species richness and evenness increase, so the diversity increases.

Simpson index values (D) are between $0-1$. The value of 1 represents infinite diversity and 0 no diversity. But while calculating, final result divided by 1 to correct the reciprocal proportion.

$\mathrm{D}=\sum n_{i}\left(n_{i}-1\right) / N(N-1)$

$\mathrm{D}=1 / \mathrm{D}$ (for reciprocal proportion)

Where D is Simpson Diversity Index, $\mathrm{n}_{\mathrm{i}}$ is Number of individuals belonging to i species, and $\mathrm{N}$ is total number of individuals,

\section{Margalef Diversity Index}

It shows a variation depending upon the number of species. Thus, it's used for comparison of sites (Kocataş, 1992).

$$
\mathrm{d}=(\mathrm{S}-1) / \ln \mathrm{N}
$$


Where d is Margalef Diversity Index,

$S$ is total number of species and

$\mathrm{N}$ is Total number of individuals.

\section{Clustering}

Estimation of species present in each habitat was clustered by applying Bray-Curtis Cluster Analysis. Biodiversity Pro Version 2 software was used for clustering of different habitats.

\section{Results}

\section{Estimation of bird species density}

Percentage distribution of bird species at 8 different study sites, recorded during habitat survey in the vicinity of Benazir Bhutto International Airport, Islamabad is given in (Table 2). Combined data of species density is given in Table 1. Majority of target bird species were prevalent in all the habitats, however, some species preferred certain habitats over the others. Results of species density of commercial habitat (Site 1) with dominant feature including hotels, mess, public parks and commercial area, showed dominance of kite population (66 percent) in this area with distribution of other species ranging between 2-7 percent.

Results of species density of commercial habitat with dominant markets, shops, plazas, vacant lot and open garbage dumps (Site 2) showed that kite population was again dominant (62 percent) in this area with distribution of other species ranging between 3-21 percent. More number of Myna was present at this site as compared to that on site 1 .

At naturally preserved recreational area (Site 3), crow was the most dominant specie (59 percent), followed by kite (26 percent). Kite, crow, house martin and myna were the most dominant birds recorded on study sites. Kite was the most prevalent species at site 1 (66 percent), site 2 (62 percent) and site 4 ( 81 percent) and ranked second at site 3 (26 percent) and at site 6 (31 percent). House martin was the dominant species only at site 5 (76 percent). Although, myna was not the dominant species at any site, however, it was found at site 1 ( 7 percent), site 2 ( 21 percent), site 7 ( 4 percent) and site 8 ( 8 percent). Crow was recorded as dominant species at site 3 (59 percent), at site 6 (57 percent), at site 7 (93 percent) and site 8 (81 percent) (Table-2).

Table-1. Cumulative bird species density recorded during habitat survey at eight selected study sites in Rawalpindi during 2012-16

\begin{tabular}{|c|c|c|c|c|c|c|c|c|c|c|c|}
\hline \multirow{2}{*}{$\begin{array}{l}\text { Study } \\
\text { Sites }\end{array}$} & \multicolumn{11}{|c|}{ Bird Species (Density/m²) } \\
\hline & Kite & Crow & Pigeon & Myna & Dove & Sparrow & Drongo & Egret & Bulbul & $\begin{array}{l}\text { House } \\
\text { Martin }\end{array}$ & $\begin{array}{c}\text { Mean Bird } \\
\text { density of Sites }\end{array}$ \\
\hline Site 1 & 0.00348 & 0.00032 & 0.00026 & 0.00038 & 0.00008 & 0.00028 & 0.00024 & 0.00000 & 0.00020 & 0.00000 & 0.00052 \\
\hline Site 2 & 0.00428 & 0.00023 & 0.00000 & 0.00143 & 0.00008 & 0.00040 & 0.00011 & 0.00000 & 0.00000 & 0.00036 & 0.00069 \\
\hline Site 3 & 0.00305 & 0.00675 & 0.00020 & 0.00048 & 0.00030 & 0.00011 & 0.00017 & 0.00013 & 0.00033 & 0.00000 & 0.00115 \\
\hline Site 4 & 0.00487 & 0.00029 & 0.00019 & 0.00019 & 0.00017 & 0.00015 & 0.00000 & 0.00000 & 0.00017 & 0.00000 & 0.00060 \\
\hline Site 5 & 0.00061 & 0.00221 & 0.00022 & 0.00052 & 0.00027 & 0.00019 & 0.00000 & 0.00072 & 0.00025 & 0.01616 & 0.00212 \\
\hline Site 6 & 0.00448 & 0.00829 & 0.00000 & 0.00019 & 0.00051 & 0.00138 & 0.00000 & 0.00000 & 0.00000 & 0.00000 & 0.00149 \\
\hline Site 7 & 0.00048 & 0.02984 & 0.00019 & 0.00094 & 0.00000 & 0.00011 & 0.00021 & 0.00013 & 0.00000 & 0.00000 & 0.00319 \\
\hline Site 8 & 0.00029 & 0.00711 & 0.00000 & 0.00070 & 0.00017 & 0.00026 & 0.00000 & 0.00000 & 0.00025 & 0.00000 & 0.00088 \\
\hline $\begin{array}{l}\text { Mean } \\
\text { Density }\end{array}$ & 0.00269 & 0.00688 & 0.00013 & 0.00060 & 0.00020 & 0.00036 & 0.00009 & 0.00012 & 0.00015 & 0.00206 & 0.00133 \\
\hline
\end{tabular}

where Site 1: Mall road, Site 2: Saddar, Site 3: Ayub Park, Site 4: Ketchery, Site 5: Swan, Site 6: KRL ground, Site 7: 30 end of runway, Site 8: Bahria Town 
Table-2. Average bird population at each study site around BBIA, Islamabad

\begin{tabular}{|l|c|c|c|c|c|c|c|c|}
\hline $\begin{array}{l}\text { Bird } \\
\text { species }\end{array}$ & Site 1 & Site 2 & Site 3 & Site 4 & Site 5 & Site 6 & Site 7 & Site 8 \\
\hline Kite & 27.35 & 33.59 & 23.92 & 38.22 & 4.75 & 35.18 & 3.80 & 2.25 \\
\hline Crow & 2.51 & 1.82 & 52.95 & 2.25 & 17.33 & 65.10 & 227.21 & 55.81 \\
\hline Pigeon & 2.00 & 0.00 & 1.58 & 1.50 & 1.75 & 0.00 & 0.00 & 0.00 \\
\hline Myna & 3.00 & 11.21 & 3.75 & 1.46 & 4.10 & 1.50 & 10.20 & 5.52 \\
\hline Dove & 0.66 & 0.66 & 2.33 & 1.33 & 2.09 & 2.60 & 1.00 & 1.33 \\
\hline Sparrow & 2.16 & 3.17 & 0.83 & 1.16 & 1.50 & 10.83 & 0.83 & 2.00 \\
\hline Drongo & 1.90 & 0.83 & 1.33 & 0.00 & 0.00 & 0.00 & 1.66 & 0.00 \\
\hline Egret & 0.00 & 0.00 & 1.00 & 0.00 & 5.66 & 0.00 & 1.00 & 0.00 \\
\hline Bulbul & 1.57 & 0.00 & 2.55 & 1.33 & 2.00 & 0.00 & 0.00 & 2.00 \\
\hline $\begin{array}{l}\text { House } \\
\text { Martin }\end{array}$ & 0.00 & 2.83 & 0.00 & 0.00 & 126.83 & 0.00 & 0.00 & 0.00 \\
\hline
\end{tabular}

where Site 1: commercial hotel of Mall road, Site 2: commercial habitat of Saddar, Site 3: naturally preserved recreational area of Ayub Park, Site 4: building with old trees at Ketchery chowk, Site 5: water body at Swan, Site 6: sports ground of KRL, Site 7: land fil site of 30 end of runway, Site 8: Modern housing society of Bahria Town

\section{K-Dominance Species Abundance Model}

Species abundance was calculated by using KDominance species abundance model to find out the abundance of each bird species out of the total abundance (100) at every selected site (Table 3). Kite although was found to be abundant species at site 4, site 1 and site 2, among all bird species, however its maximum abundance was recorded at site 4 (81 percent) where old building were situated along with tall trees (Table 3).

\section{Simpson's Biodiversity Index}

K-Dominance abundance model does not tell us much about the species diversity, Simpson's biodiversity index, as it calculates species diversity taking into consideration both the richness and evenness (Table 4) that naturally preserved area of site 3 had the maximum biodiversity index (2.428) followed by site 6 (2.398), site 2 (2.352), while site 1 showed lowest value (1.168).

\section{Margalef Diversity Index}

Margalef Diversity Index shows the richness of birds at any site (Türkmen and Kazanci, 2010). The data analysed according to Margalef Diversty Index is shown in Table 5. The results showed highest value of bird richness at site 1 (5.574) followed by site 4 (5.374) while the lowest value was found for site 7 (3.765). The variation in the Margalef Diversity Index is due to the fact that it takes into account the number of species, and not the number of individuals.

\section{Bray-Curtis Cluster Analysis}

Habitat Composite index calculated in habitat analysis to classify the habitats on the basis of presence of similarities and dissimilarities of bird attractants at a particular site represented in the form of Bray-Curtis coefficient (Clarke et al., 2016). Cluster formation of similarities matrix indicated that $80 \%$ similarity existed between site 1 (Commercial habitat with hotels, mess and pine trees) and site 4 (buildings with old pine trees), both these sites had dominance of kite species. Seventy-nine percent similarities were found between naturally preserved recreational area of sites 3 and 6 which represented sports ground area (Fig 1). These sites had abundance of crow species. Sites 3 and 8 were similar (79 percent) on the basis of presence of crows at these sites. Seventy-six percent similarity existed again between commercial habitats of site 1 and 2. Dominant species at these two sites were kites (Table-2 \& 3).

Table-3. K-Dominance Species Abundance Model of different habitats surrounding BBI Airport

\begin{tabular}{|c|c|c|c|c|c|c|c|c|c|c|c|c|c|c|c|}
\hline \multicolumn{2}{|c|}{ Site 1} & \multicolumn{2}{|l|}{ Site 2} & \multicolumn{2}{|c|}{ Site 3} & \multicolumn{2}{|c|}{ Site 4} & \multicolumn{2}{|l|}{ Site 5} & \multicolumn{2}{|c|}{ Site 6} & \multicolumn{2}{|c|}{ Site 7} & \multicolumn{2}{|c|}{ Site 8} \\
\hline Kite & 66.429 & Kite & 62.07 & Crow & \begin{tabular}{|l|}
58.661 \\
\end{tabular} & Kite & 80.841 & house martin & 76.399 & Crow & 56.5 & Crow & 92.47 & Crow & 80.99 \\
\hline Myna & 73.72 & Myna & 82.78 & Kite & 85.17 & Crow & 85.62 & Crow & 86.84 & Kite & 87.04 & Myna & 96.62 & Myna & 88.99 \\
\hline Crow & 79.83 & Sparrow & 88.63 & Myna & 89.32 & Pigeon & 88.79 & Egret & 90.25 & Sparrow & 96.44 & Kite & 98.17 & Kite & 92.26 \\
\hline Sparrow & 85.09 & house martin & 93.87 & Bulbul & 92.15 & Myna & 91.89 & Kite & 93.11 & Dove & 98.69 & Drongo & 98.85 & Sparrow & 95.16 \\
\hline Pigeon & 89.95 & Crow & 97.23 & Dove & 94.74 & Dove & 94.71 & Myna & 95.58 & Myna & 100 & Dove & 99.25 & Bulbul & 98.06 \\
\hline Drongo & 94.56 & rongo & 98.77 & Pigeon & 96.49 & Bulbul & 97.53 & Ove & 96.84 & Pigeon & 100 & Egret & 99.66 & Dove & 100 \\
\hline Bulbul & 98.38 & Dove & 100 & Drongo & 97.97 & Sparrow & 100 & Bulbul & 98.04 & Drongo & 100 & Sparrow & 100 & Pigeon & 100 \\
\hline Dove & 100 & Pigeon & 100 & Egret & 99.07 & Drongo & 100 & Pigeon & 99.09 & Egret & 100 & Pigeon & 100 & Drongo & 100 \\
\hline Egret & 100 & Egret & 100 & Sparrow & 100 & Egret & 100 & Sparrow & 100 & Bulbul & 100 & Bulbul & 100 & Egret & 100 \\
\hline
\end{tabular}

\section{Note: the values of bird population are in cumulative percentages}

where Site 1: commercial hotel of Mall road, Site 2: commercial habitat of Saddar, Site 3: naturally preserved recreational area of Ayub Park, Site 4: building with old trees at Ketchery chowk, Site 5: water body at Swan, Site 6: sports ground of KRL, Site 7: land fil site of 30 end of runway, Site 8: Modern housing society of Bahria Town 


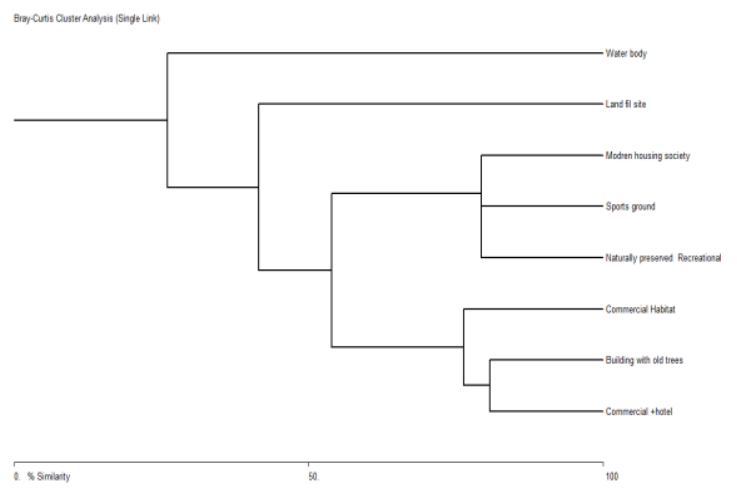

Figure-1. Similarity of Different Habitats on the basis of various bird species (Bray-Curtis Cluster Analysis)

Table-4. The Simpson Biodiversity Index of all eight study sites

\begin{tabular}{|l|c|c|}
\hline Index & $\begin{array}{c}\text { Simpsons Diversity } \\
(\mathrm{D})\end{array}$ & $\begin{array}{c}\text { Simpsons Diversity } \\
(1 / \mathrm{D})\end{array}$ \\
\hline Site 1 & 0.446 & $\mathbf{2 . 2 4 3}$ \\
\hline Site 2 & 0.425 & $\mathbf{2 . 3 5 2}$ \\
\hline Site 3 & 0.412 & $\mathbf{2 . 4 2 8}$ \\
\hline Site 4 & 0.653 & 1.532 \\
\hline Site 5 & 0.595 & 1.68 \\
\hline Site 6 & 0.417 & $\mathbf{2 . 3 9 8}$ \\
\hline Site 7 & 0.857 & 1.168 \\
\hline Site 8 & 0.661 & 1.514 \\
\hline
\end{tabular}

Table-5. Margalef Diversity Index of all eight study sites

\begin{tabular}{|l|c|}
\hline Index & Margalef M Base 10. \\
\hline Site & 5.574 \\
\hline Site 2 & 5.192 \\
\hline Site 3 & 4.602 \\
\hline Site 4 & 5.374 \\
\hline Site 5 & 4.054 \\
\hline Site 6 & 4.366 \\
\hline Site 7 & 3.765 \\
\hline Site 8 & 4.896 \\
\hline
\end{tabular}

where Site 1: commercial hotel of Mall road, Site 2: commercial habitat of Saddar, Site 3: naturally preserved recreational area of Ayub Park, Site 4: building with old trees at Katchery chowk, Site 5: water body at Swan, Site 6: sports ground of KRL, Site 7: land fil site of 30 end of runway, Site 8: Modern housing society of Bahria Town

\section{Discussion}

Following bird species were identified in the surrounding area of the airport. These species showed variation in richness and evenness in different type of habitats.

\section{House crow (Corvus Splendens)}

House crow (Corvus Splendens), belonging to family Corviadea, were distributed throughout in all study sites along the survey route (Table-1). However highest densities of crow were recorded at study sites 7 (3-0 end of runway), 8 (Bahria Town), 3 (Ayub park) (Table 2) respectively. Crows were observed exploiting all feeding opportunities available in habitats like open garbage dumps located outside Sarwar park at Site 1, garbage dump at Saddar, on grassy fields of sports grounds of KRL cricket stadium and in nearby garbage dumps, water bodies of Soan, in public parks, in commercial and also in naturally preserved areas of Ayub park. It was found feeding on household refuse, kitchen leftovers, insects, earthworms, cockroaches, grasshoppers, fruits, grains, carrion, and road kills. Highest numbers of crow were observed at site 7 near runway 30 end. Roost of crow averaging $1655 \pm 153$ bird were recorded inside the airport boundary along, to the northeast of runway 3-0 in dense strip of mixed strands of Paper Mulberry (Broussonetia papyrifera) Eucalyptus (Eucalyptus camaldulensis) and Indian rose wood (Dalbergis sisso). Similarly, relatively higher crow density was recorded at site 8 (Bahria Town), 3 Ayub park and near KRL cricket stadium. Crows were found nesting in Eucalyptus trees (Eucalyptus camaldulensis) present at site 6 and 7, Paper Mulberry (Broussonetia papyrifera), Albizzia lebbek, Cupressus sempervirnes, Dalbergia sisso,Morus alba,populous nigra,salmalia malbarica at Ayub park and roosting dominantly in (Acacia modesta) at Bahria Town.

\section{Kite (Milvus migrans)}

Kite (Milvus migrans) (belonging to family Accipitridae, were also distributed throughout in all study sites (Table 1). These birds of prey were observed soaring high and occupying most of the airspace in the vicinity of the airport. Kites were observed feeding on carrion, frogs, lizards, insects, chicken, dead animals killed in road accidents, fish from water bodies of Lai and Soan, household garbage and refuse available at open garbage dumps, moles and rats (Paliwal and Bhandarkar, 2017). Highest numbers of kites were observed at site 4 in Fatimah Jinnah University at Kacheri Chwk. Roosts of kite averaging 20-30 birds on each tree, were found associated with pine trees present inside Fatima Jinnah Women University, and Punjab house in the nearby vicinity. Trees present at this site are very old and tall, kite nests 
were found associated with these tall pine trees. Our results showed that site 1,2,3,4 and 6 showed higher density of kite (Milvus migrans) than at site 5 (Table 3 ) Kites were found associated mainly with tall trees of Pinus roxburghii, Dalbergia sisso, Eucalyptus camaldulensis and were seen nesting and roosting on these trees (Mehta and Ilyas, 2018). Structures like telephone towers, tall buildings were also utilized for nesting as their nesting sites. Kites (Milvus migrans) were also observed sitting high on the boards and logos mounted at the top of these buildings. Kites were the largest birds soaring high in the study area. Flock of kites, with average number 20-30 birds were often found hovering over Fatima Jinnah University, Saddar, near Golf Club, Ayub park and Saddar area. This flocking and soaring behavior of these massive birds is critically dangerous for safe aircraft operation at these sites (Moreno-Opo and Margalida, 2017). Moreover, keeping in mind the breeding seasons of the species, effective control methods could be devised. It was observed that pairing in kite began during the months of Oct-Nov. During this period birds were observed producing special call signs. Pair was found actively involved in chasing each other, both the sexes were found taking part in nest building. It has been observed that same nest was used in the next year. At these study sites, Kites (Milvas migrans) preferred nesting on tall plantation especially Pinus roxburgii ranging in estimated height of 35-45 ft on, Eucallyptus camaldulensis (30-35 ft), Dalbergis Sisso ( 25-30 ft) and on telephone poles approximately $(60-70 \mathrm{ft})$ in height and tall buildings (50-60 ft in height). Female kites were present around their nest during egg laying (Dec-Jan) and hatching season.

First chicks were observed emerging from their nests at the end of April to late May and some time the period extended to June. The juvenile was observed fledging during the months of May-June. 13 kite nests were observed. One on telephone towers at site 8 , three at site 3 , four at site 1 , five at site 4 . Average height of these kite nests from the ground level was 15-20 m.

\section{Myna (Acridotheres tristis)}

Common myna (Acridotheres tristis) belonging to family, were also distributed evenly in all study sites along the survey route (Table 1). Mynas were observed to nest in tree cavities at Sarwar park and Ayub Park and also cavities made in mud near site 8 (Bahria Town). Like house crows, they were also found exploiting all feeding opportunities available in habitats i.e. open garbage dumps located at site
$1,2,4,7$, on grassy fields of sports grounds site 6 , near water bodies of site 5 , in public parks site 1 , in commercial and also in naturally preserved areas (site 3). It was found feeding on household refuse, kitchen leftovers, insects, earthworms, cockroaches, grasshoppers, fruits thrown out from vegetable shops, grains, carrion, and road kills.

\section{Black Drongo (Dicrurus macrocercus)}

Black drongo were observed mainly at site 1, 2, 3 and 7 (Table 1). This bird was found perching on branches, overhead cables or power line. These birds mainly fed on insects like grasshoppers, bees, ants, moths, dragonflies, mosquitoes. They were found associated with common myna, egrets and other birds near garbage transfer stations in the vicinity of the airfield and other sites near water bodies of Soan and Lai.

\section{Bulbul (Pycnonotus cafer)}

These birds were observed mainly in Sarwar park (Site 1), gardens, lawns of hotels (PC and Shalimar) and natural area with vegetation (Ayub park and Bahria town) (Table 1). Bulbul were found around shrubs of rose Rosa indica, Hibiscus rosa-sinensis, Bougainvillea glabra, pomegranate (Punica granatum), guava (Psidium guajava) and date palm (Phoniex dactylifera) plum (Syzygium cumini), Kachnar ( Bauhinia variegata) citrus Citrus sinensis, Ficus carica, trees at these sites.

\section{Egret (Egretta alba)}

Egrets were found near water bodies of site 5 and 7 (Table 3). They were observed feeding along with myna, kites and crows near garbage dumps under Soan bridge, at Shaheen Town near runway 30 end and were observed exploiting feed from Soan river (Arshad et al., 2015). These birds were also observed in Ayub park. Population of egrets was not observed in commercial areas of site 1,2 and near site 4 .

\section{Pigeon (Columbia livia) and Dove (Streptopelia decaocto)}

The doves and pigeons were observed mainly in all habitats except for site 7 garbage dumping site (Table 1). These birds have been well settled in urban areas. Pigeons were observed inhibiting in wide variety of natural and urban environment. They were found in crevices and cracks, under bridges and in buildings. Pigeon keeping is also a very common hobby in many areas of Rawalpindi. Dove were mainly concentrated 
at Ayub park, site 3 where they were seen feeding on ground, grass, grains and utilizing, trees, branches and overhead cables as perching sites.

\section{House Sparrow (Passer domesticus)}

Passer domesticus was widely spread and abundant in all habitats of these study sites, however highest density of this species was recorded in KRL sports ground (Table 2), where flocks of sparrow were seen feeding on fields of cricket stadium. It is a commensal species found exploiting food from household refuse, garbage dumps, insects, grains and seeds from grasses. They nest usually in cavities or utilize structure such as shades of street lights, holes in window sills, buildings. Both sexes take part in nest formation.

\section{House Martin (Delichon urbicum)}

A colony of house martin, of about 1500-2500 birds, was found underneath the Soan Bridge. Nests were made of mud in cup like structure.

There were swarms of mosquitoes in the area (probably the most abundant feeding resource available for martins). Other birds, including kites (Milvus migrans), egrets (Egretta alba), myna (Acridotheres tristis) and crows (Corvus Splendens) were observed exploiting feeding opportunities available at dumping site.

\section{Conclusion}

The main objective of this study was to identify hazardous bird species, richness, evenness and their habitat preferences around Benazir Bhutto International Airport Islamabad, Pakistan.

Kites (Milvus migrans) were found to be the main species of concern in this area based on their size and behavior. In addition, variation in habitat like naturally preserved recreational areas, commercial habitats, habitat near water bodies, landfill sites, housing societies, buildings with tall tree plantation and open garbage dumping sites also showed abundance and diversity of other bird species too, thus creating possible potential problems to aircraft operations at BBIA. It is unlikely that the airport authorities will be able to prevent bird strike risk arising from the birds' prevalence in the vicinity of the BBIA due to the abundance of attractive sites in its surroundings. However, keeping in mind land use practices, bird densities, evenness, richness, bird behavior, feeding preferences, breeding cycles, nesting and knowledge about roosting perching sites obtained by the results of this study could help airport authorities for devising effective bird control measures to mitigate bird strike risk. This information could be incorporated to develop site specific bird management plan for BBIA, Islamabad.

\section{Disclaimer: None. \\ Conflict of Interest: None. Source of Funding: None.}

\section{References}

Arshad S, Hussain I, Anwar M and Mirza SN, 2015. Habitat survey for recognizing bird attractants around Benazir Bhutto International Airport, Islamabad, Pakistan. Pak. J. Agric. Res. 28(3): 263-271.

Belant JL, 1997. Gulls in urban environments: landscape-level management to reduce conflict. Landscape Urban Plan. 38: 245-258.

Bildstein, KL, 2017. Raptors: the curious nature of diurnal birds of prey. Cornell University Press, USA.

CAA, 2017. Pakistan CAA Public Awareness Message Against Laser Lights, Kite Flying \& Garbage Throwing Near Airports. Pakistan Civil Aviation Authority. https://historyofpia.com/forums/viewtopic.php?t= 25266

Clarke KR, Somerfield PJ and Gorley RN, 2016. Clustering in non-parametric multivariate analyses. J. Exp. Marine Biol. Ecol. 483: 147-155.

Dénes FV, Tella JL and Beissinger SR, 2018. Revisiting methods for estimating parrot abundance and population size. Emu-Austral Ornithol. 118(1): 67-79.

Dolbeer RA, Arrington DP, LeBoeuf E and Atkins C, 1996. Can Albatrosses and aircraft coexist on Midway Atoll? In: Proceedings of Birdstrike Committee Europe. 23: 327- 335.

Dolbeer RA, 1998. Population dynamics: the foundation of wildlife damage management for the 21st century. Pp: 2-11. In: Proceedings of the $18^{\text {th }}$ Vertebrate Pest Conference. Eds. R. O.Baker and C. Crabb. University of California, Davis, USA.

Dolbeer RA, Wright SE and Cleary EC, 2000. Ranking the hazard level of wildlife species to aviation.Wildl. Soc. Bull. 28(2): 373-378.

Hingston AB, Wardlaw TJ, Baker SC and Jordan GJ, 2018. Data obtained from acoustic recording units 
and from field observer point counts of Tasmanian forest birds are similar but not the same. Aust. Field Ornithol. 35:30-39.

Hutto RL, Letschet MP and Hendricks P, 1986. A fixed-radius point count method for non-breeding and breeding season use. Auk. 103: 593-602.

Kocataş A, 1992. Ecology and environmental biology. University of the Aegean printing, İzmir, Turkey. p. 564.

Lazebnik J, Dicke M, terBraak CJ and van Loon JJ, 2017. Biodiversity analyses for risk assessment of genetically modified potato. Agric. Ecosyst. Environ. 249: 196-205.

Matthew DN, Sreekumar S, Joseph KT, Gangadharan M, Jacob TT and Kumar MM, 1998. Experiences of the voluntary zoologist and experts of the Calicut University, in reducing bird hazards in the aerodromes of Trivandrum, Cochin, Calicut, Mangalore and Ramnad, India. IBSC. In: $24^{\text {th }}$ Meeting, Stara Lesna, Slovakia. 16: 1-15.

Mattos AE and Peris S, 2008. Influence of time of day, duration and number of point counts in point count sampling of birds in an Atlantic forest of Paraguay. Ornitol. Neotrop. 19: 229-242.

Mehta A and Ilyas O, 2018. Factors affecting nest site selection of Milvus migrans govinda (pariah kite), in and around amu campus, Aligarh. Int. J. Avian Wildlife Biol. 3(4): 272-277.

Moreno-Opo R and Margalida A, 2017. Large birds of prey, policies that alter food availability and air traffic: a risky mix for human safety. Human Wildlife Interact. 11(3): 339-343.

Paliwal GT and Bhandarkar SV, 2017. Ecology and conservation of threatened birds in and around Navegaon National Park, Maharashtra. Int. J. Environ. Rehab. Conserv. 8(1): 120-135.
Plummer KE, Risely K, Toms MP and Siriwardena GM, 2019. The composition of British bird communities is associated with long-term garden bird feeding. Nature Commun. 10(1): 1-8.

Servoss W, Engeman RM, Fairaizl S, Cummings JL and Groninger NP, 2000. Wildlife hazard assessment for Phoenix Sky Harbor International Airport. Int. Biodeterior. Biodegrad. 45: 111-127.

Türkmen GE and Kazanci NI, 2010. Applications of various biodiversity indices to benthic macroinvertebrate assemblages in streams of a national park in Turkey. Rev. Hydrobiol. 3(2): 111-125.

Upadhyaya BK and Dolbeer RA, 2001. Management of bird and other wildlife hazards at Tribhuvan International Airport, Kathmandu, Nepal. In: 2001 Bird Strike Committee -USA/ Canada. Third Joint Annual Meeting, Calgary, AB. 27: 13.

Washburn BE and Seamans TW, 2007. Wildlife responses to vegetation height management in cool season grassland. Rangeland Ecol. Manage. 60: 319-323.

Witmer GW and Fantinato JW, 2003. Management of rodent population at airports. Proceedings of the $10^{\text {th }}$ Wildlife Damage Management Conference. pp. 350-358.

\section{Contribution of Authors}

Arshad S: Conceived idea, designed study, collected and analysed data and article write up Malik AM: Helped in literature review, data collection, analysis and article write up 